\title{
Long-term evolution of highly alkaline steel slag drainage waters
}

\author{
Alex L. Riley (D) - William M. Mayes
}

Received: 11 December 2014 / Accepted: 16 June 2015 / Published online: 25 June 2015

(C) Springer International Publishing Switzerland 2015

\begin{abstract}
The disposal of slag generated by the steel industry can have negative consequences upon the surrounding aquatic environment by the generation of high $\mathrm{pH}$ waters, leaching of potentially problematic trace metals, and rapid rates of calcite precipitation which smother benthic habitats. A 36-year dataset was collated from the long-term ambient monitoring of physicochemical parameters and elemental concentrations of samples from two steel slag leachate-affected watercourses in northern England. Waters were typified by elevated $\mathrm{pH}(>10)$, high alkalinity, and were rich in dissolved metals (e.g. calcium (Ca), aluminium (Al), and zinc ( $\mathrm{Zn})$ ). Long-term trend analysis was performed upon $\mathrm{pH}$, alkalinity, and $\mathrm{Ca}$ concentration which, in addition to $\mathrm{Ca}$ flux calculations, were used to highlight the longevity of pollution arising as a result of the dumping and subsequent leaching of steel slags. Declines in calcium and alkalinity have been modest over the monitoring period and not accompanied by significant declines in water $\mathrm{pH}$. If the monotonic trends of decline in alkalinity and calcium continue in the largest of the receiving streams, it will be in the region of 5080 years before calcite precipitation would be expected to be close to baseline levels, where ecological impacts would be negligible.
\end{abstract}

Electronic supplementary material The online version of this article (doi:10.1007/s10661-015-4693-1) contains supplementary material, which is available to authorized users.

A. L. Riley $(\bowtie) \cdot$ W. M. Mayes

Centre for Environmental and Marine Sciences, University of

Hull, Scarborough YO11 3AZ, UK

e-mail: A.Riley@2014.hull.ac.uk
Keywords Slag · Hyperalkaline · Trend analysis . Calcite precipitation $\cdot$ Pollution

\section{Introduction}

As a ubiquitous by-product of steel production, around 61 million tonnes (Mt) of steel slag is generated yearly worldwide. Over half of this (33 Mt per annum) is produced within the USA and Europe (Proctor et al. 2000; Motz and Geiseler 2001), with an additional 27 Mt from China and Japan (Shen and Forssberg 2003), and 1.2 Mt from Russia (Smirnov et al. 2009). While there have been long-standing after-uses for steel byproducts in construction (e.g. Motz and Geiseler 2001; Shi 2004), as soil amendments (Zhuo et al. 2012) and in environmental engineering applications (Kruse et al. 2012; Goetz and Riefler 2014), a proportion of steel slags produced end up being disposed of in landfill sites - a reported $35 \%$ of total steel slag produced in Europe (Motz and Geiseler 2001). Given these potentially varied after-uses, there has been interest in many quarters concerning any potential negative environmental impacts that may arise during environmental weathering (e.g. Navarro et al. 2010) either in construction after-uses or disposal (Schwab et al. 2006). Large databases of aqueous and solid phase information have been collated from laboratory leaching tests (e.g. De Windt et al. 2011; Fällman 2000; and Tossavainen and Lind 2008), while protocols for such leaching tests have been proposed to ensure consistency in results (NVN 1994; Poultney 2013). These data provide a useful 
context for assessing potential environmental risks. However, there is a paucity of studies that detail the leaching products of steel slag weathering under ambient environmental conditions.

Roadcap et al. (2006) provided a benchmark study documenting the extreme $\mathrm{pH}$ associated with groundwaters and spring resurgence from a major slag-fill aquifer in Illinois, USA. Elevated concentrations of aqueous calcium, fluoride and chromium were also reported. Mayes et al. (2008, 2009a) and Hull et al. (2014) detail the chemical composition of slag leachates at a range of UK sites. The waters all showed a consistent major ion matrix of $\mathrm{Ca}-\mathrm{CO}_{3}-\mathrm{OH}$-type waters, with enrichment of a range of trace elements. These included some elements that do not typically feature on the analytical suite of most environmental regulators as part of ambient water quality monitoring such as vanadium, lithium and molybdenum (Hull et al. 2014). Other workers have highlighted the presence and mobility of various potential environmental contaminants that form oxyanions under high $\mathrm{pH}$. Chaurand et al. (2007) highlighted the presence of vanadium in its pentavalent form (vanadate) under highly alkaline conditions. Such concerns, and notably the vanadium mobility, are common to other alkaline residues such as bauxite processing residue (e.g. Burke et al. 2013) and coal combustion residues (Rattner et al. 2006). In addition to vanadium, chromium, barium and molybdenum have been highlighted as elements of concern in steel slag leaching products (Fällman and Hartlén 1994; Chaurand et al. 2007; Matern et al. 2013).

As well as the extreme $\mathrm{pH}$ and potential mobility of oxyanion-forming contaminants, steel slag waters are also characterised by vigorous rates of precipitation of secondary carbonate minerals which can smother the stream beds (Koryak et al. 2002; Roadcap et al. 2006). The negative impacts of such waters on aquatic biota has been highlighted by Koryak et al. (2002) who observed diminished diversity of invertebrate and fish populations in a stream affected by steel slag leachate from a riparian slag disposal area. More recently, Hull et al. (2014) showed total invertebrate abundance and diversity to be negatively correlated with $\mathrm{pH}$, with an impoverished benthic fauna around source areas $\mathrm{pH}$ 10.4-11.8). Interestingly, invertebrate communities were seen to recover over relatively small spatial scales as $\mathrm{pH}$ of the streams buffered towards a $\mathrm{pH}$ of 9 (Hull et al. 2014).

While these studies provide a useful insight into some of the chemical and biological impacts arising from slag disposal, there are very few accounts of the longevity of these pollution issues. Long-term water quality records are crucial for under-pinning environmental management strategies (Burt et al. 2011), and this is particularly pertinent at legacy pollution sources where remediation interventions often fall on the public purse (Jarvis et al. 2006; Jarvis and Younger 1997). For the analogous pollution issue of discharges from abandoned mines, such long-term monitoring often shows a 'first flush' of very poor quality water being released after mine closure, or groundwater rebound (Younger 1997). This is subsequently followed by an asymptotic decay in metal concentrations (e.g. Younger and Banwart 2002; Mayes et al. 2011). As such, short-term intensive management interventions may be required immediately after mine decommissioning (e.g. lime dosing), with less capital-intensive approaches such as settlement lagoons and wetlands (Mayes et al. 2009a, b) or even monitored natural attenuation, being more suitable over longer term decadal timescales.

This paper aims to provide an overview of the longterm evolution and nature of steel slag drainage from a major former steelworks site in the UK. A 36-year water quality record is used to (1) assess the hydrogeochemical nature of the steel slag leachates, (2) assess long-term trends in the data, and (3) consider the broader management issues associated with such legacy sites.

\section{Materials and methods}

\section{Study site}

Two sample stations are located on watercourses draining extensive slag mounds associated with the former Consett Iron and Steel Works in northern England (54 50'32.9386" N, 001 ${ }^{\circ} 51^{\prime} 32.5752^{\prime \prime} \mathrm{W}$ and 54 51' 11.7661" N, 001 51' 38.0473" W) (Fig. 1). These streams were dosed with sulphuric acid during the active operation of the steel mill which ceased in 1980 (Howel et al. 2001). Under baseflow conditions, the Dene Burn receives around half of its flow from drainage networks beneath an area of the site known as Grove Heaps. Steel production by-products were disposed of on these heaps up until the closure of the Works, and as such, the heaps consist primarily of blast furnace bottom and steel slag (Mayes et al. 2008). These slag deposits, in addition to ashes and site demolition wastes, sit over superficial alluvium and glacial till above Lower Coal 
Measures of Carboniferous (Westphalian) age. Another large, separate subterranean drainage system to the north of the Dene Burn emerges to a stream known as Howden Burn. This second sample station was used to analyse contaminants introduced from the area previously occupied by the main steel plant, blast furnaces and coke works. White precipitates were observed at both sites to smother the stream bed, forming amorphous deposits in low flow areas and hard flowstonelike formations in more turbulent areas. Both the Howden and Dene Burn flow into the River Derwent, which was also sampled by the chief environmental regulator in England, the Environment Agency, upstream (at Allensford - site code 43400041) and downstream (at Shotley Bridge — site code 43400039) of the steel mill site (Fig. 1). These sample stations are used to assess the broader impact of the former steelworks on instream water quality given no other major tributaries influence the Derwent between these sample stations.

\section{Sampling}

Samples presented represent a combined dataset of ambient monitoring by the UK environmental regulator (Environment Agency and precursor organisations: 1978-2003) and data collected by the authors (2001present). Sample frequency for samples collected by official monitoring agencies varies over time with up to 24 samples taken in some years, with an average of 5 samples taken. Full details of sample parameters, sample size and range of collection are provided in the Supporting Information. For samples collected by the authors, a Myron L Ultrameter ${ }^{\circledR}$ was used to measure the physical and chemical parameters $(\mathrm{pH}$, oxidationreduction potential (ORP), electrical conductivity (at $25^{\circ} \mathrm{C}$ ), temperature) of samples in situ. Accuracy of results was assured through regular calibration of the ultrameter to standards of known $\mathrm{pH}(12.4,10,7$ and 4). A Hach digital titrator was used to measure total sample alkalinity at all sites in the field by means of a fixed endpoint titration (Hach reference 8203) of filtered $(0.45 \mu \mathrm{m})$ sample against $1.6 \mathrm{~N} \mathrm{H}_{2} \mathrm{SO}_{4}$ using bromocresol green-methyl red indicator (to $\mathrm{pH} 4.6$ ).

Major anion species within samples were analysed using a Dionex 100 Ion Chromatograph in addition to major cation and minor elemental composition of leachate samples being determined using a Perkin Elmer Elan DRCII Inductively Coupled Plasma-Mass Spectrometer (ICP-MS; for As, Cr, Li, Mo, Sb and V: detection limits

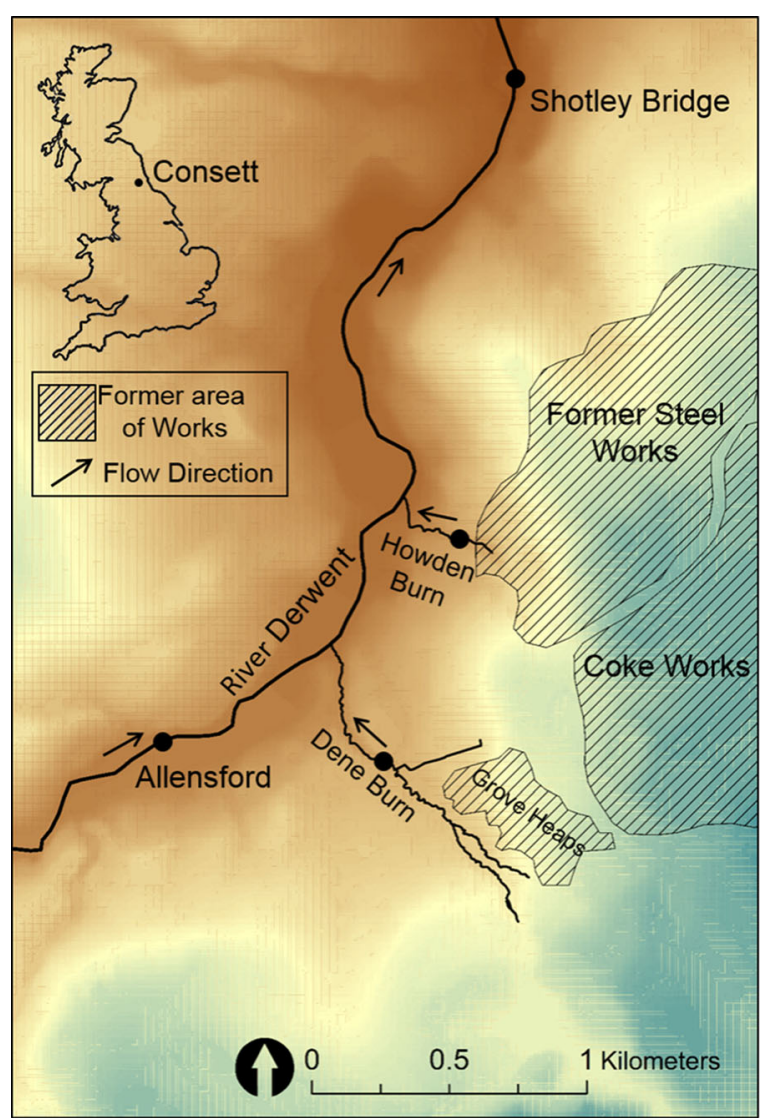

Fig. 1 Site map of Dene and Howden Burn, showing locations relative to River Derwent and slag deposits and topography (blue $=$ high, brown=low)

1-5 ppb) and a Perkin Elmer Optima 5300 DV ICPOES (all other elements: detection limits 10-100 ppb). For aqueous samples, charge balances on selected full analyses were within $10 \%$. All Environment Agency water samples were analysed in accredited laboratories.

Daily rainfall data was provided by the Environment Agency for the nearby Ebchester Westwood rainfall gauge station $\left(50^{\circ} 17^{\prime} 41.9388^{\prime \prime} \mathrm{N},-6^{\circ} 55^{\prime} 15.5532^{\prime \prime}\right.$ W). Daily flow measurements were not available for the River Derwent at sample sites Allensford or Shotley Bridge. In order to calculate approximate $\mathrm{Ca}$ flux to the Derwent, analogous flow measurements were calculated using the median gauged daily flow provided by the National River Flow Archive (NRFA) of stations upstream and downstream of the confluence with Dene and Howden Burn-Derwent at Eddys Bridge (station ID 23002) and Derwent at Rowlands Gill (station ID 23007). 
Data analysis

Saturation indices for calcite are computed from major physicochemical parameters and major ion data using the geochemical code PHREEQC v.1.5.10 (Parkhurst and Apello 1999) with the WATEQ4F (Ball and Nordstrom 1991) database. The solubility product of vaterite $\left(\mathrm{CaCO}_{3}\right)\left(10^{-7.91}\right)$ was added from Plummer and Busenberg (1982).

Data were highly skewed even after transformation (Kolmogorov-Smirnov $P<0.05$ ) so non-parametric methods were used to assess relationships between elements and physicochemical parameters (Spearman rank test) and when comparing averages between the upstream and downstream sites on the River Derwent (Mann-Whitney). For trend analysis, given the gaps in the time series, seasonal assessment of trend was not possible (e.g. seasonal Mann-Kendall test: Hirsch and Slack 1984). As such, a partial Mann-Kendall test was undertaken on key variables indicative of slag leachate $(\mathrm{pH}, \mathrm{Ca}$, total alkalinity) with flow from the River Derwent used as a covariate (Libiseller and Grimvall 2002). Statistical analyses were undertaken in R ( R Development Core Team 2012) and MULTMK/PARTMK (Libiseller and Grimvall 2002) for trend analyses.

\section{Results}

Discharge chemistry

Slag drainage waters sampled were typified by very high $\mathrm{pH}$ and alkalinity and exceeded predefined Environmental Quality Standards (EQS) prescribed in the UK for aquatic life for $\mathrm{pH}$ at both the Dene and Howden Burn (Table 1). Metal concentrations within leachateaffected streams were also elevated and characteristic of the parent material through which the water percolated. The high $\mathrm{CaO}$ content of steel and ferrous slags and high $\mathrm{Al}_{2} \mathrm{O}_{3}$ content in certain steel slags (Shi 2004) leads to enhanced concentrations of $\mathrm{Ca}$ and $\mathrm{Al}$ in leachates. Trace metals were prevalent at source sample sites, notably $\mathrm{Cd}, \mathrm{Cr}$ and $\mathrm{Zn}$. The presence of these elements within slags and drainage waters is a direct result of their addition to molten steel during smelting and additional refining processes (Das et al. 2007). Of the trace metals monitored at $\mathrm{HB}$ and $\mathrm{DB}$, only $\mathrm{Cu}$ and $\mathrm{Zn}$ breached quality standards, although concentrations of metals such as $\mathrm{Cd}$ and $\mathrm{Pb}$ at Howden Burn were approaching upper limits of acceptability. The scope of chemical data available for the river Derwent was not as wide as that for the Dene and Howden Burn and as such, only comparisons of $\mathrm{pH}$, alkalinity and $\mathrm{Ca}$ can be made. Median sample $\mathrm{pH}$ at Allensford (7.7) was significantly lower (Mann-Whitney $U$ test, $\mathrm{W}=23237.5, P<0.001$ ) than the downstream sample point at Shotley Bridge (7.9) after the confluence of Dene and Howden Burn to the Derwent. The downstream increase in $\mathrm{pH}$ was also accompanied by significant increases in alkalinity (from 38.95 to $45.75 \mathrm{mg} / \mathrm{l}$; Mann-Whitney $U$ test, $\mathrm{W}=$ 19758.5, $P<0.001$ ) and calcium concentration (from 15.6 to $20.5 \mathrm{mg} / \mathrm{l}$; Mann-Whitney $U$ test, $\mathrm{W}=11262.5$, $P<0.001)$. While metal concentrations were generally greater downstream at Shotley Bridge (Table 1), only $\mathrm{Cu}$ was significantly higher (Mann-Whitney $U$ test, $\mathrm{W}=$ 62753, $P<0.001)$. Interestingly, $\mathrm{Zn}$ was significantly higher upstream of leachate inputs (Mann-Whitney $U$ test, $\mathrm{W}=86897, P<0.001$ ), likely to be due to the influence of base metal mines further upstream (Mayes et al. 2011). Although EQS guidelines were not exceeded, this increase in $\mathrm{pH}$ downstream (along with significant increases of alkalinity and $\mathrm{Ca}$ concentration) suggest that not only the Dene and Howden Burn are adversely affected by slag leachates, but the combined effect of these two streams also influences the larger River Derwent system in to which they drain.

\section{Correlations}

Statistical analysis of the physicochemical parameters and elemental composition of samples revealed multiple significant correlations within the streams affected by steel slag leachate. In-stream $\mathrm{pH}$ exhibited strong positive (Spearman rank, $P<0.001$ ) correlations with alkalinity and $\mathrm{Ca}$ at both the Dene and Howden Burn (Tables 2 and 3). At the Howden Burn, pH also showed a highly significant positive correlation with conductivity of samples, although this was not the case at Dene Burn. As for correlations between chemical and hydrological parameters, negative relationships were observed between $\mathrm{pH}$ and rainfall at Howden Burn (Table 2), and $\mathrm{pH}$ and flow at Dene Burn (Table 3). Negative correlations were also apparent between flow and $\mathrm{Ca}$ at both sample sites. The frequency distribution of $\mathrm{pH}$ in both the Dene and Howden Burn are also both heavily left-skewed (Fig. 2) which supports such patterns of occasional dilution of perennial groundwaterdominated flows from within the slag mounds by 
Table 1 Mean physical and chemical characteristics of samples

\begin{tabular}{|c|c|c|c|c|c|c|c|c|c|c|c|c|c|c|c|c|c|c|}
\hline & & \multicolumn{8}{|c|}{ Slag drainage } & \multicolumn{8}{|l|}{ Derwent } & \multirow[b]{2}{*}{ EQS } \\
\hline & & DB Med & Max & Min & $N$ & HB Med & Max & Min & $N$ & AL Med & Max & Min & $N$ & SB Med & Max & Min & $N$ & \\
\hline $\mathrm{pH}$ & & 10.3 & 12.3 & 7.3 & 75 & 10.89 & 12.7 & 6.5 & 144 & 7.7 & 8.5 & 6.7 & 166 & $7.9^{\mathrm{a}}$ & 9.23 & 6.9 & 172 & $6-9$ \\
\hline Cond & $\mu \mathrm{S}$ & 1005 & 1150 & 860 & 2 & 1800 & 4356 & 1200 & 33 & - & - & - & - & - & - & - & - & - \\
\hline Alk & $\mathrm{mg} / \mathrm{l}$ & 75.8 & 902 & 21 & 68 & 110 & 3570 & 15 & 121 & 38.9 & 105 & 10 & 151 & $45.5^{\mathrm{a}}$ & 187 & 10 & 159 & - \\
\hline $\mathrm{SO}_{4}$ & $\mathrm{mg} / \mathrm{l}$ & 117 & 320 & 32 & 55 & 755 & 2700 & 42 & 91 & - & - & - & - & - & - & - & - & - \\
\hline $\mathrm{Ca}$ & $\mathrm{mg} / \mathrm{l}$ & 58 & 805 & 9 & 49 & 149 & 315 & 9.3 & 86 & 15.55 & 30.1 & 1.54 & 126 & $20.5^{\mathrm{a}}$ & 182.2 & 2.06 & 135 & - \\
\hline $\mathrm{Al}$ & $\mu \mathrm{g} / 1$ & 120 & 2610 & 50 & 62 & 106.5 & 5000 & 0.397 & 86 & - & - & - & - & - & - & - & - & - \\
\hline $\mathrm{Cd}$ & $\mu \mathrm{g} / 1$ & 0.1 & 25 & 0 & 61 & 0.2 & 181 & 0.003 & 96 & 0.06 & 0.4 & 0.02 & 37 & - & - & - & - & 5 \\
\hline $\mathrm{Cr}$ & $\mu \mathrm{g} / \mathrm{l}$ & 1.4 & 15 & 0.1 & 60 & 10 & 110 & 0.02 & 96 & 1 & 3 & 0.235 & 102 & 1 & 71.5 & 0.03 & 225 & 50 \\
\hline $\mathrm{Cu}$ & $\mu \mathrm{g} / \mathrm{l}$ & 3.3 & 20 & 1 & 63 & 7.46 & 3600 & 0.002 & 98 & 1.275 & 5.58 & 0.485 & 136 & $1.55^{\mathrm{a}}$ & 5.64 & 0.837 & 115 & 28 \\
\hline $\mathrm{Ni}$ & $\mu \mathrm{g} / 1$ & 8.1 & 109 & 0 & 48 & 5 & 390 & 0.009 & 97 & 2.68 & 13 & 1 & 107 & 3.23 & 9.53 & 1 & 220 & 200 \\
\hline $\mathrm{Pb}$ & $\mu \mathrm{g} / \mathrm{l}$ & 8.2 & 590 & 0 & 51 & 8.45 & 520 & 0.1 & 96 & 1.805 & 19 & 0.6 & 136 & 4.64 & 125 & 1.95 & 115 & 20 \\
\hline $\mathrm{Zn}$ & $\mu \mathrm{g} / 1$ & 20 & 635 & 5 & 54 & 20 & 330 & 0.009 & 99 & $24.15^{\mathrm{a}}$ & 271 & 8 & 290 & 21.3 & 590 & 6 & 259 & 7.8 \\
\hline
\end{tabular}

EQS Environmental Quality Standard, - data not available, $A L$ Allensford, $S B$ Shotley Bridge

${ }^{a}$ For Derwent sites: significantly higher than other Derwent sample location

surface runoff. Significant inter-metal (Al, $\mathrm{Ca}, \mathrm{Cd}, \mathrm{Cr}$, $\mathrm{Cu}, \mathrm{Ni}$ and $\mathrm{Pb}$ ) correlations were all positive at both sites, indicative of a common source for the metals at both sites which would be the metal-rich slag deposits from with the leachates emerged.
Trends

Partial Mann-Kendall (PMK) tests were used to investigate long-term trends in particular physical and chemical parameters that had the most complete time series at

Table 2 Correlation matrix of variables at Howden Burn

\begin{tabular}{|c|c|c|c|c|c|c|c|c|c|c|c|c|c|}
\hline HB & $\mathrm{pH}$ & Cond & Alk & $\mathrm{Ca}$ & $\mathrm{RF}$ & Flow & $\mathrm{Al}$ & $\mathrm{Cd}$ & $\mathrm{Cr}$ & $\mathrm{Cu}$ & $\mathrm{Ni}$ & $\mathrm{Pb}$ & $\mathrm{SO}_{4}$ \\
\hline Cond & $0.485^{* *}$ & & & & & & & & & & & & \\
\hline Alk & $0.496^{* *}$ & 0.114 & & & & & & & & & & & \\
\hline $\mathrm{Ca}$ & $0.567 * *$ & N/A & $0.516^{* *}$ & & & & & & & & & & \\
\hline $\mathrm{RF}$ & $-0.224^{*}$ & -0.132 & -0.169 & -0.255 & & & & & & & & & \\
\hline Flow & -0.146 & -0.153 & -0.112 & $-0.292 * *$ & $0.298 * *$ & & & & & & & & \\
\hline $\mathrm{Al}$ & -0.111 & N/A & 0.187 & -0.159 & -0.028 & 0.116 & & & & & & & \\
\hline $\mathrm{Cd}$ & $0.231^{*}$ & N/A & $0.596^{* *}$ & $0.285^{* *}$ & -0.217 & 0.041 & $0.305^{* *}$ & & & & & & \\
\hline $\mathrm{Cr}$ & $0.248 *$ & N/A & $0.409 * *$ & $0.484 * *$ & 0.047 & 0.131 & 0.063 & $0.669 * *$ & & & & & \\
\hline $\mathrm{Cu}$ & $0.23^{*}$ & N/A & $0.665^{* *}$ & $0.259^{*}$ & 0.055 & 0.038 & $0.333^{* *}$ & $0.703^{* *}$ & $0.596^{* *}$ & & & & \\
\hline $\mathrm{Ni}$ & $0.293 * *$ & N/A & $0.653 * *$ & $0.436^{* *}$ & -0.034 & 0.018 & $0.316^{* *}$ & $0.79 * *$ & $0.756^{* *}$ & $0.732 * *$ & & & \\
\hline $\mathrm{Pb}$ & $0.016^{*}$ & N/A & $0.585^{* *}$ & $0.365^{* *}$ & -0.130 & -0.109 & $0.374 * *$ & $0.825^{* *}$ & $0.648^{* *}$ & $0.716^{* *}$ & $0.758^{* *}$ & & \\
\hline $\mathrm{SO}_{4}$ & $0.392 * *$ & $0.696^{*}$ & $0.017^{*}$ & $0.449 * *$ & -0.029 & -0.124 & -0.230 & -0.045 & 0.034 & 0.010 & 0.047 & -0.051 & \\
\hline $\mathrm{Zn}$ & -0.171 & N/A & 0.011 & 0.039 & 0.122 & -0.013 & $0.362 * *$ & 0.193 & $0.259^{*}$ & $0.294^{* *}$ & 0.149 & $0.378^{* *}$ & $-0.23 *$ \\
\hline
\end{tabular}

Maximum $N$ value $=177$ (pH-flow), minimum $N$ value $=9\left(\right.$ Cond- $\left.-\mathrm{SO}_{4}\right)$

$R F$ rainfall, Alk alkalinity, Cond conductivity

${ }^{*} P>0.05 ; * * P<0.001$ (Spearman rank) 
Table 3 Correlation matrix of variables at Dene Burn

\begin{tabular}{|c|c|c|c|c|c|c|c|c|c|c|c|c|}
\hline DB & $\mathrm{pH}$ & Cond & Alk & $\mathrm{Ca}$ & $\mathrm{RF}$ & Flow & $\mathrm{Al}$ & $\mathrm{Cd}$ & $\mathrm{Cr}$ & $\mathrm{Cu}$ & $\mathrm{Ni}$ & $\mathrm{Pb}$ \\
\hline Cond & -0.365 & & & & & & & & & & & \\
\hline Alk & $0.395^{* *}$ & -0.254 & & & & & & & & & & \\
\hline $\mathrm{Ca}$ & $0.452 * *$ & -0.738 & $0.32 *$ & & & & & & & & & \\
\hline $\mathrm{RF}$ & -0.170 & 0.929 & $-0.467 * *$ & -0.265 & & & & & & & & \\
\hline Flow & $-0.22 * *$ & 0.281 & $-0.395^{* *}$ & $-0.399 * *$ & $0.249 *$ & & & & & & & \\
\hline $\mathrm{Al}$ & -0.166 & N/A & -0.06 & -0.246 & 0.239 & 0.140 & & & & & & \\
\hline $\mathrm{Cd}$ & -0.202 & N/A & 0.229 & -0.261 & -0.128 & 0.083 & $0.361^{* *}$ & & & & & \\
\hline $\mathrm{Cr}$ & $-0.287^{*}$ & N/A & $0.307^{*}$ & 0.062 & -0.107 & $0.259^{*}$ & 0.204 & $0.578 * *$ & & & & \\
\hline $\mathrm{Cu}$ & $-0.253 *$ & N/A & $0.308^{*}$ & -0.013 & 0.080 & 0.135 & $0.482 * *$ & $0.596 * *$ & $0.704 * *$ & & & \\
\hline $\mathrm{Ni}$ & -0.168 & N/A & -0.005 & 0.197 & -0.005 & -0.110 & $0.327^{*}$ & $0.412 * *$ & 0.260 & $0.404 * *$ & & \\
\hline $\mathrm{Pb}$ & -0.197 & N/A & 0.125 & -0.144 & -0.060 & 0.033 & $0.624 * *$ & $0.552 * *$ & $0.321 *$ & $0.606^{* *}$ & $0.356^{* *}$ & \\
\hline $\mathrm{SO}_{4}$ & 0.216 & N/A & $0.289^{*}$ & $0.695 * *$ & 0.001 & $-0.321 *$ & -0.207 & $0.346^{*}$ & 0.209 & 0.144 & 0.26 & \\
\hline $\mathrm{Zn}$ & -0.040 & N/A & -0.081 & 0.239 & -0.332 & 0.049 & $0.493 * *$ & $0.346^{* *}$ & 0.204 & $0.336^{* *}$ & $0.429 * *$ & $0.385^{* *}$ \\
\hline
\end{tabular}

Maximum $N$ value $=145$ (pH-flow), minimum $N$ value $=4$ (Cond-Ca)

$R F$ rainfall, $A l k$ alkalinity

$* P>0.05 ; * * P<0.001$ (Spearman rank)

both sites ( $\mathrm{pH}$, alkalinity, Ca). The use of flow as a covariate accounts for the fluctuations in leachate chemistry driven by transient hydrological events. The significant relationships between flow and some of the leachate characteristics highlighted above provide good justification for the PMK approach in this case (Libiseller and Grimvall 2002).

Total alkalinity of samples from Dene Burn showed a significant $(P<0.001)$ reduction over time during the monitoring record (Fig. 3; Table 4). Calcium concentration also exhibited a significant decline in the Dene Burn with a noisy, albeit monotonic decay at a rate of $0.36 \mathrm{mg} / \mathrm{l} \mathrm{Ca} /$ year over the 30-year period (Fig. 3). Despite slight spikes in Ca concentration in the early 1990s and spikes in alkalinity in the late 1980s (when no corresponding Ca data were available), this over-arching trend would suggest either diminishing input of $\mathrm{Ca}-\mathrm{OH}$ to the systems from point sources (i.e. leachate discharges) with progressive weathering of slag deposits, or changes in surface drainage that are leading to dilution by surface runoff. Given there was no significant change in flow over the sampling period (PMK, Mann-Kendall statistic 425, slope $0.0005 ; P>0.05$ ), it is more likely that reduced $\mathrm{Ca}$ and alkalinity input from slag leachates is the reason for the observed trend in the Dene Burn. This fall in $\mathrm{Ca}$ and alkalinity does not however correspond with a fall in $\mathrm{pH}$ in the Dene Burn. No significant change in $\mathrm{pH}$ is apparent in the Dene Burn $\mathrm{pH}$ record (Table 4), although $\mathrm{pH}$
Fig. 2 The frequency distribution of $\mathrm{pH}$ in the Howden Burn (left) and Dene Burn (right) over the 36-year data series (after Mayes et al. 2008)
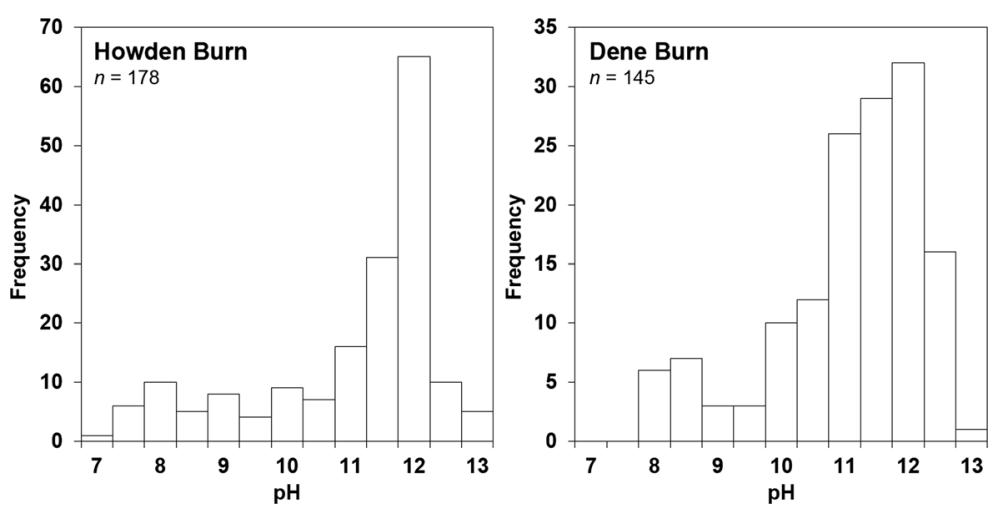
Fig. 3 Trends in $\mathrm{pH}$, total alkalinity and calcium in the Dene Burn. Data show individual data points (closed circles), annual averages (open squares with standard deviation on $y$ error bars) and trend lines as per the Sen's slope method. Blue lines indicate a significant declining trend $(P<0.05)$; black lines show no significant $(P>0.05)$ trend
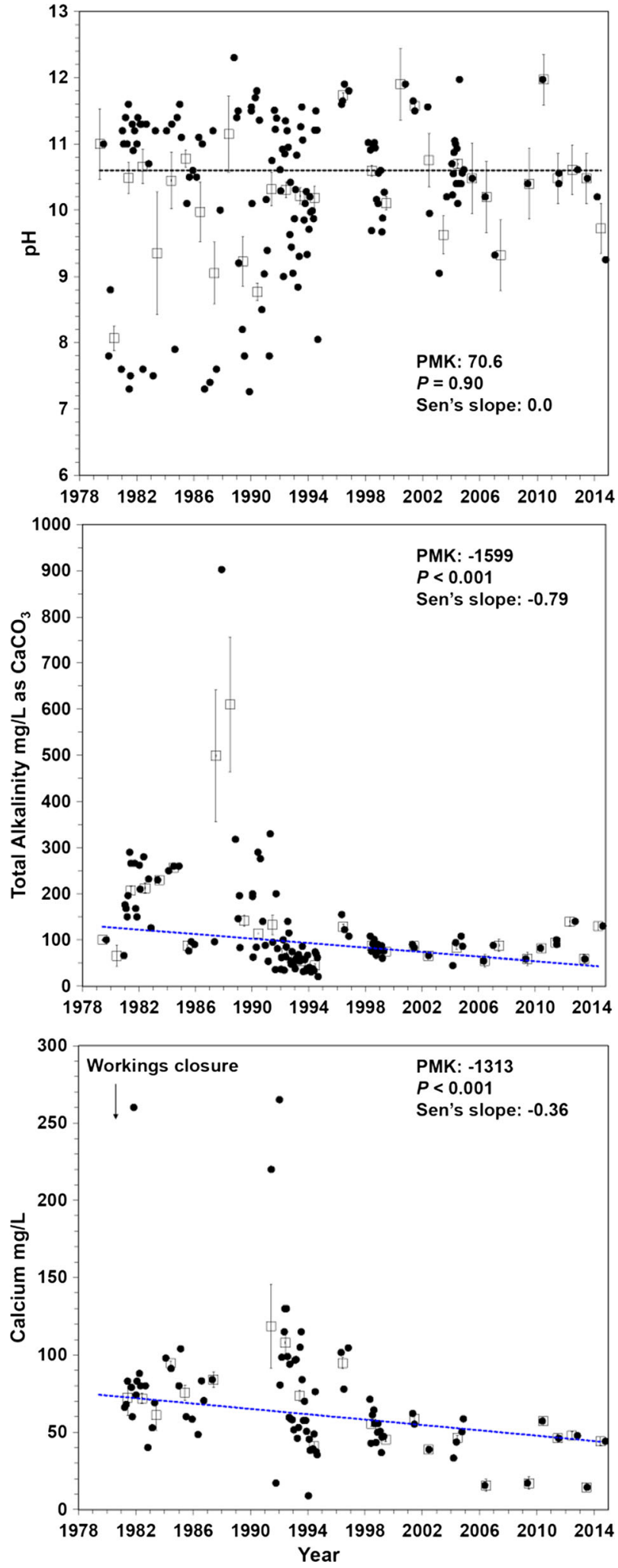
Table 4 Results of partial Mann-Kendall trend analysis on pH, calcium (Ca) and total alkalinity (Alk) in the Dene Burn and Howden Burn

\begin{tabular}{|c|c|c|c|c|c|c|c|c|c|c|c|c|}
\hline \multirow{3}{*}{$\begin{array}{l}\text { Stream } \\
\text { Analysis period } \\
\text { Parameter }\end{array}$} & \multicolumn{3}{|c|}{ Dene Burn } & \multicolumn{9}{|c|}{ Howden Burn } \\
\hline & \multicolumn{3}{|c|}{ 1978-2014 } & \multicolumn{3}{|c|}{ 1978-2014 } & \multicolumn{3}{|c|}{ 1978-1999 } & \multicolumn{3}{|c|}{$2000-2014$} \\
\hline & $\mathrm{pH}$ & $\mathrm{Ca}$ & Alk & $\mathrm{pH}$ & $\mathrm{Ca}$ & Alk & $\mathrm{pH}$ & $\mathrm{Ca}$ & Alk & $\mathrm{pH}$ & $\mathrm{Ca}$ & Alk \\
\hline$N$ & 145 & 87 & 107 & 180 & 100 & 140 & 144 & 122 & 86 & 36 & 18 & 14 \\
\hline PMK test statistic & -26 & $-1357 * *$ & $-1655^{* *}$ & $2563 *$ & $-925^{*}$ & -260 & 506 & $-2023 * *$ & $-1258 * *$ & $291^{* *}$ & 30 & 5 \\
\hline Sen's slope & 0 & -0.36 & -0.79 & 0.004 & -0.48 & -0.08 & 0.002 & -0.86 & -0.99 & 0.03 & 2.17 & 1.24 \\
\hline
\end{tabular}

Flow as a covariate did not show a significant trend in any test

$* P<0.05 ; * * P<0.001$ (significant)

maxima were generally apparent in the early (1980-1990) part of the data record.

The trends in key parameters in the Howden Burn are less clear. While a significant decline in $\mathrm{Ca}$ is accompanied by a significant rise in $\mathrm{pH}$ $(P<0.05)$ and no trend in alkalinity $(P>0.05)$, there appear to be two distinct phases within the time series: from 1978 up until 2000, then 2000 to present (Fig. 4; Table 4). When trend analysis is undertaken on the separate intervals in the time series (Fig. 4; Table 4), a significant decline is apparent in both alkalinity and $\mathrm{Ca}$ from 1978 to 1999. This decline is not accompanied by any significant change in $\mathrm{pH}$ over the same period, which shows that the waters are well-buffered by hydroxide alkalinity. For the latter period of the data record in the Howden Burn (1999-2014), no significant change in alkalinity or $\mathrm{Ca}$ is apparent, although an increase in $\mathrm{pH}$ is observed over this relatively short data record (Fig. 4).

\section{Saturation indices}

Saturation indices $(S I)$ of polymorphs of calcium carbonate provide a useful measure of the propensity of the hyperalkaline drainage waters to precipitate carbonate on the benthic habitats affected by the slag discharges. These were computed for all data points with a minimum concurrent availability of $\mathrm{pH}, \mathrm{Ca}$ and total alkalinity data. The relationship between $S I_{\text {calcite }}$ and $\mathrm{Ca}$ across both streams is shown in Fig. 5. As would be expected given the form of the SI equation, a significant $(P<0.001)$ log-linear relationship is apparent between the variables. Superimposed on Fig. 5 are the two values for $S I_{\text {calcite }}$ that are often quoted for heterogeneous (+ $0.3)$ and homogeneous $(+1.5)$ precipitation of calcite (Ford and Williams 2007). It is apparent that the majority of samples ( $84 \%$ ) fall well above the lower threshold where calcite precipitation would be anticipated on an existing surface, with $64 \%$ samples above the higher threshold where calcite precipitation in solution would be expected (Ford and Williams 2007).

Table 5 shows the median and range of $S I$ values for relevant calcium carbonate polymorphs observed in the Howden and Dene Burn for different phases of the observational record at the Consett site. As would be anticipated with the significant monotonic fall in total alkalinity and $\mathrm{Ca}$ in the Dene Burn, there is a concurrent fall in $S I$ values from the immediate post-closure years where a median $S I_{\text {calcite }}$ of +1.95 was apparent (1980 1985) to recent monitoring (2005-2014) in the Dene Burn where $S I_{\text {calcite }}$ is 0.98 . Similarly high median $S I_{\text {calcite }}$ values were apparent in the early monitoring phases in the Howden Burn (1.74-2.10). However, these values are in a similar range through to the present day monitoring (Table 4), which is consistent with the total alkalinity and $\mathrm{pH}$ data which have not shown a significant fall over the full data record, despite an initial decay up to 2000 .

\section{Ca flux estimates}

The observed increase in $\mathrm{Ca}$ concentration along the Derwent, after the confluence of Dene and Howden Burn (Table 1), prompted further analysis to assess the extent of Ca input to the system. Using available data for $\mathrm{Ca}$ and calculated flow approximations, $\mathrm{Ca}$ loading to the Derwent was assessed to give insight to the total 
Fig. 4 Trends in $\mathrm{pH}$, total alkalinity and calcium in the Howden Burn. Data show individual data points (closed black circles), annual averages (open squares with standard deviation on y error bars) and trend lines as per the Sen's slope method. Red line shows a significant rising trend $(P<0.05)$, blue lines a significant declining trend $(P<0.05)$ and black lines show no significant $(P>0.05)$ trend. Trend lines are given for the entire data record (1978-2014) and the periods 1978-1999 and 2000-2014 (see text)
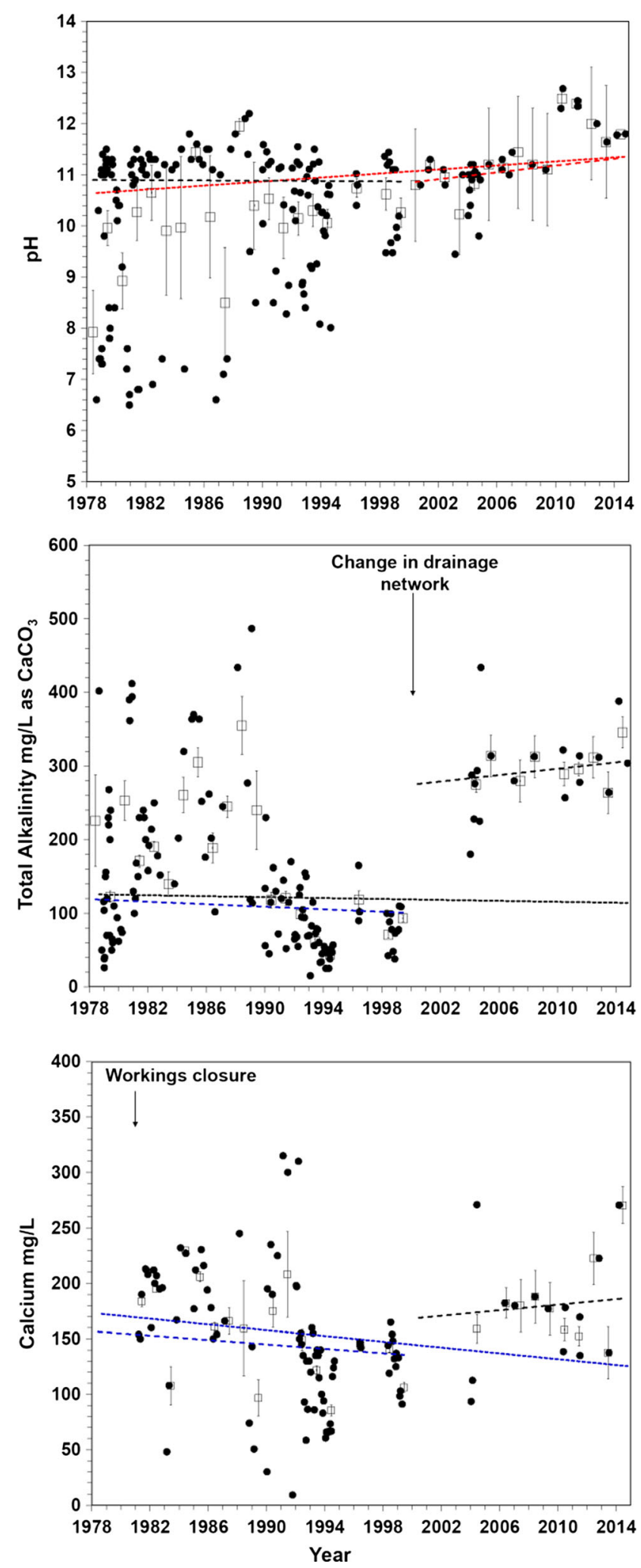


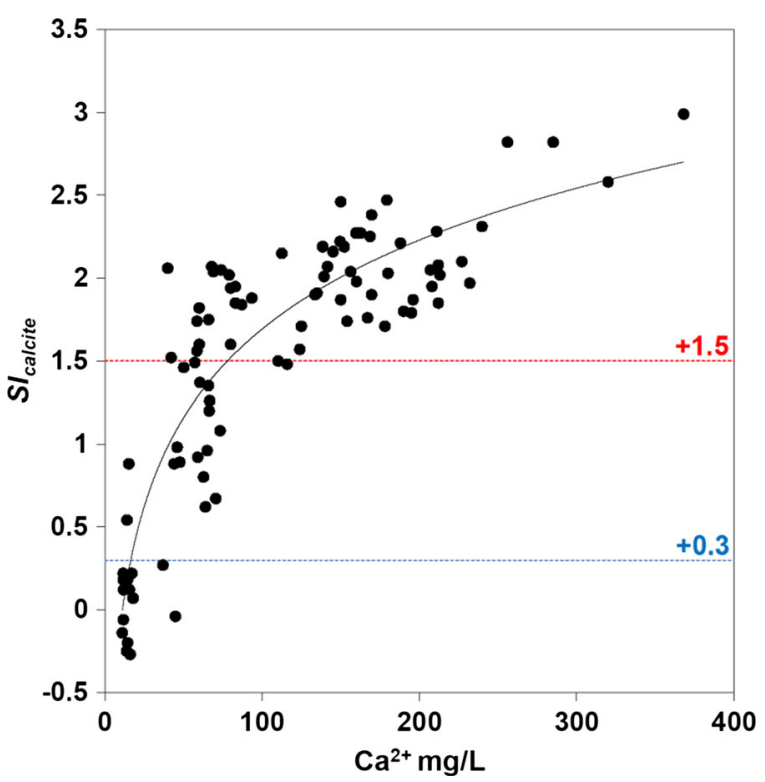

Fig. 5 The relationship between calcium concentration and the saturation index for calcite. Trend line shows significant log-linear relationship $\left(r^{2} 78.9\right.$, ANOVA $\left.F 340, d f 92, P<0.001\right)$. Blue and red horizontal thresholds represent those typically considered for heterogeneous and homogeneous calcite precipitation, respectively (Ford and Williams 2007)

quantity leaching from the slag heaps. Results of loading calculations revealed a total release of over $2400 \mathrm{t} \mathrm{Ca}$ to the Derwent from 1991 to 2003, in the region of $17.2 \mathrm{t}$ of $\mathrm{Ca}$ per month. Although large, this figure only represents the portion of $\mathrm{Ca}$ which remained dissolved in the water column - the true amount leached from waste heaps would actually be higher due to Ca lost from solution during rapid precipitation of Ca-bearing minerals (e.g. calcite, aragonite $\left(\mathrm{CaCO}_{3}\right)$ and vaterite) in close proximity to leachate emergence.

\section{Discussion \\ Leachate chemistry}

The disposal of steel slag residues poses a threat to surface water quality downstream of disposal sites due to the emergence of metal-rich leachates, the hyperalkaline $\mathrm{pH}$ and the rapid formation of mineral precipitates. The hydro-geochemistry of leachate samples encountered at Howden and Dene Burn were characterised by elevated $\mathrm{pH}$, alkalinity and trace metal concentrations (Table 1). These results were consistent with those previously reported at steel slag disposal sites (Roadcap et al. 2006; Mayes et al. 2008) and within other alkaline waste leachates, such as coal combustion residues (e.g. Hjelmar 1990). The prevalence of $\mathrm{CaO}$ and other $\mathrm{Ca}-\mathrm{Mg}$ oxides and silicates as a by-product in steel production is the main factor influencing and driving the high $\mathrm{pH}$ of waters percolating through and emerging from slag heaps. The hydrolysis of $\mathrm{Ca}$ oxides by water results in the formation of calcium hydroxide (as portlandite), which then dissociates in solution to form $\mathrm{Ca}^{2+}$ ions and, importantly, hydroxyl $\left(\mathrm{OH}^{-}\right)$ions which are responsible for the increase in $\mathrm{pH}$ (Roadcap et al. 2006). In aquatic settings, the effect of increased $\mathrm{pH}$ can be detrimental to aquatic life, as reported by Hull et al. (2014) who witnessed negative correlations between invertebrate abundance and diversity with $\mathrm{pH}$ at

Table 5 Saturation indices (SI) for calcite (and selected $\mathrm{CaCO}_{3}$ polymorphs) for the Dene Burn (1980-1984 and 2004-2014) and Howden Burn (1981-1986 and 2004-2014)

\begin{tabular}{|c|c|c|c|c|c|c|}
\hline & \multicolumn{3}{|c|}{ Dene Burn (1980-1984) } & \multicolumn{3}{|c|}{ Dene Burn (2004-2014) } \\
\hline & Calcite & Aragonite & Vaterite & Calcite & Aragonite & Vaterite \\
\hline Median SI & 1.95 & 1.74 & 1.45 & 0.98 & 0.83 & 0.48 \\
\hline Min & 1.6 & 1.39 & 1.11 & 0.12 & -0.03 & -0.39 \\
\hline Max & 2.07 & 1.86 & 1.57 & 1.66 & 1.51 & 1.16 \\
\hline \multirow[t]{3}{*}{$N$} & 12 & 12 & 12 & 11 & 11 & 11 \\
\hline & \multicolumn{3}{|c|}{ Howden Burn (1981-1986) } & \multicolumn{3}{|c|}{ Howden Burn (2004-2014) } \\
\hline & Calcite & Aragonite & Vaterite & Calcite & Aragonite & Vaterite \\
\hline Median SI & 1.91 & 1.76 & 1.41 & 2.03 & 1.88 & 1.53 \\
\hline Min & 1.74 & 1.58 & 1.23 & 1.71 & 1.56 & 1.21 \\
\hline Max & 2.1 & 1.95 & 1.59 & 2.21 & 2.06 & 1.71 \\
\hline$N$ & 14 & 14 & 14 & 11 & 11 & 11 \\
\hline
\end{tabular}


streams associated with steel slag leachate. Although invertebrate communities in the Hull et al. (2014) study were seen to recover rapidly over small spatial scales downstream of leachate inputs, consistent $\mathrm{pH}$ values above environmental quality standards have been shown to negatively affect populations of higher organisms such as cyprinid fish (Koryak et al. 2002).

The increased $\mathrm{pH}$ of streams draining steel slag deposits at Consett not only affects the biotic environment directly, but also indirectly by mineral precipitation (e.g. calcite). At high $\mathrm{pH}$, atmospheric carbon dioxide ingasses in to the water column, reacting with the dissociation products of portlandite to rapidly form calcite (in addition to other $\mathrm{CaCO}_{3}$ polymorphs; Roadcap et al. 2005). This precipitate rapidly encrusts in-stream debris and smothers the stream bed (see Supporting Information); restricting light penetration to primary producers (Koryak et al. 2002). When high trace metal concentrations (Table 1) are coupled with the issues of high $\mathrm{pH}$ in leachate-affected streams, the resulting diminished water quality poses problems for ensuring good chemical and ecological quality of Dene and Howden Burn as set out in the Water Framework Directive (2000/60/EC).

Metal concentrations within samples posed only intermittent issues with respect to water quality. Zinc concentration, although exceeding quality standard by more than twofold, is not anticipated to cause ecological problems due to the limited availability of zinc at the hardness of water encountered (Paulauskis and Winner 1988). $\mathrm{Pb}$ levels in the Howden Burn are consistently above EQS values while there are occasional breaches of $\mathrm{Cu}$ and $\mathrm{Cr}$ also in the Howden Burn system. However, official monitoring data at the site does not include some additional potential contaminants of concern that can be present in steel slag leachates such as vanadium (Chaurand et al. 2007), which have previously been documented at the site (Hull et al. 2014).

Sample $\mathrm{pH}$ was shown to positively correlate with alkalinity and $\mathrm{Ca}$ concentration within leachates (Tables 2 and 3). This relationship may be explained by the hydrolysis of $\mathrm{CaO}$ and subsequent dissociation of $\mathrm{Ca}(\mathrm{OH})_{2}$ and by the weathering at high $\mathrm{pH}$ of $\mathrm{Ca}-$ bearing minerals common within slag (e.g. rankinite $\left(\mathrm{Ca}_{3} \mathrm{Si}_{2} \mathrm{O}_{7}\right)$ ). Processes such as these, which occur as water percolates through steel slag deposits, contribute towards increased hydroxide $\left(\mathrm{OH}^{-}\right)$alkalinity of waters (Roadcap et al. 2005). This weathering also increases the concentration of dissolved $\mathrm{Ca}$ at high $\mathrm{pH}$, the reason for the positive $\mathrm{pH}-\mathrm{Ca}$ correlations identified. Sample
pH was shown to negatively correlate with rainfall (Table 2) and flow (Table 3). This is a result of dilution, whereby the relative in-stream proportion of high $\mathrm{pH}$ leachate is shifted by additional flow due to precipitation. Dilution from rainfall is also the likely explanation to the negative relationship observed between flow and Ca concentration within the Howden and Dene Burn (Tables 2 and 3).

Correlations between metals were positive at both of the leachate-affected streams. Metal concentrations at Howden Burn also showed positive relationships with stream pH (Table 2). This, along with significant positive relationships between metals at both sites, is likely result of increased trace metal concentration and mobility at high pH (Czop et al. 2011; Langmuir 1996), characteristics shared with other hyperalkaline leachates such as bauxite processing residue. Interestingly, sample $\mathrm{pH}$ and trace metal $(\mathrm{Cu}, \mathrm{Cr})$ concentrations at Dene Burn were negatively correlated (Table 3 ). This relationship may have arisen due to the relatively higher influence of surface water runoff upon the Dene Burn than the Howden Burn, leaving the stream more susceptible to flushing events from urban surfaces and associated peaks in trace metal concentration, e.g. $\mathrm{Cu}, \mathrm{Cr}$ (Nabizadeh et al. 2005; Tromp et al. 2012).

\section{Trend analysis}

The value of long-term water quality records has been highlighted by many workers (Burt et al. 2011) and is a key novelty of the site in question here. Trend analysis was performed on data for $\mathrm{pH}$, alkalinity and $\mathrm{Ca}$ at both the Dene Burn and Howden Burn. It would be expected that the heaps surrounding these watercourses would become increasingly leached and the slag depleted of free lime and other reactive oxides (Li et al. 2012) and metals. Over time, it may be anticipated that the resulting hydro-geochemistry of leachate would exhibit an asymptotic decay towards baseline conditions of $\mathrm{pH}$, $\mathrm{Ca}$ and alkalinity as is apparent in analogous cases of pollution from abandoned mines (Younger et al. 2005). However, results of analysis indicated that this was not quite the case.

Alkalinity at Dene Burn was shown to reduce significantly over time, a trend also shown by calcium concentration (Fig. 3). However, despite positive correlations between $\mathrm{pH}$ and alkalinity, and $\mathrm{pH}$ and $\mathrm{Ca}$ (Tables 2 and 3), the $\mathrm{pH}$ of the Dene Burn showed no significant change over time. This pattern is not entirely 
unexpected given the buffering of $\mathrm{pH}$ that would be expected from hydroxide at source as a continued product of the Ca-oxide weathering (Roadcap et al. 2005). The response in $\mathrm{pH}$ would not necessarily be expected to be linear and consistent with the gradual decline in $\mathrm{Ca}$ and total alkalinity (i.e. bicarbonate, carbonate and hydroxide). Evidence from other sites often shows rapid inflection points in $\mathrm{pH}$ in such highly alkaline systems when carbonate dominates sample alkalinity (Mayes et al. 2006). The long-term trends in data at Howden Burn were different from those at Dene Burn and comprised of two monitoring periods. As a whole, the dataset showed a marginal decline in $\mathrm{Ca}$ and rise in $\mathrm{pH}$ with no significant change in alkalinity. When the separate time series are assessed around the clear breakpoint in Fig. 4, a different pattern emerges. The initial decline in $\mathrm{Ca}$ concentration and alkalinity within the Howden Burn is much steeper ( $1 \mathrm{mg} \mathrm{Ca} / \mathrm{l} /$ year $)$ than in the longterm Dene Burn trend $(0.4 \mathrm{mg} \mathrm{Ca} / \mathrm{l} /$ year $)$, where $\mathrm{Ca}$ concentrations are initially much lower (Figs. 3 and 4). This finding may suggest that under ambient environmental conditions, initial $\mathrm{Ca}$ concentration has bearing on the rate at which levels would return to baseline conditions. This distinct change in the Howden Burn system is consistent with a change in drainage patterns as a result of extensive groundworks for residential and retail developments on the slag mounds the Howden Burn drains in the 1990s that can be identified on site maps (see Supporting Information). The recent dataset does not show the variability of early records (i.e. less circum-neutral $\mathrm{pH}$ events, even under high flow) which alludes to a change in drainage area with less ingress of surface runoff into the Howden Burn since the urban developments which would capture much surface runoff.

The relationship between $\mathrm{Ca}$ and $S I_{\text {calcite }}$ allows some insight into the potential longevity of the pollution issues in the affected systems. Calcium concentrations in the region of $15-25 \mathrm{mg} / \mathrm{l}$ at the site correspond to SI of + 0.2 to +0.6 (Fig. 5), where carbonate precipitation would be likely to be marginal (Ford and Williams 2007). Indeed, monitored carbonate precipitation rates in the Dene Burn from mass balance estimates at equivalent Ca concentrations suggest calcite precipitation rates in the region of $0.6-0.8 \mathrm{~g} / \mathrm{m}^{2} /$ day (Hull et al. 2014). These rates are similar to natural tufa-precipitating streams (Zaihua et al. 1995; Miliša et al. 2006) and do not have a major negative impact on the composition of macroinvertebrate communities in highly alkaline settings
(Hull et al. 2014). Following the decline in Ca apparent in the Dene Burn in the monitoring record, it would take between 52 and 80 years for such $\mathrm{Ca}$ values to be apparent in the Dene Burn assuming the monotonic trend continued. For the case of the Howden Burn, the prognosis for longevity of leachate generation is both more speculative (given the noisier historic data record: Fig. 4) and more enduring. Based on the long-term decline in $\mathrm{Ca}$ of $0.48 \mathrm{mg} / \mathrm{l} /$ year (Table 4), it would take, in excess of 150 years before $\mathrm{Ca}$ concentrations fall below $50 \mathrm{mg} / \mathrm{l}$. Given that changes in drainage patterns at the site have led to rapid changes in the chemical composition of drainage waters, such extrapolation is highly uncertain. However, the fact that the $\mathrm{pH}$ of the Howden Burn stream has shown no sign of declining in the 36-year monitoring record (and 33 years since closure of the steel plant) and the stream is devoid of macro-invertebrate life (Hull et al. 2014) highlights that the timescales over which leachate generation occur can be readily measured in decades as opposed to years.

\section{Ca flux}

In the region of 3.5 million $\mathrm{m}^{3}$ of slag was heaped during the active operation of Consett Iron and Steelworks. The constantly evolving production methods used at the former steel mill has led to the accumulation of various types of slags (Renforth et al. 2009), including blast furnace and steel slag. Given typical particle density for blast furnace and steel slags to be 2.4 and $3.6 \mathrm{~g} / \mathrm{cm}^{3}$, respectively (Euroslag 2014), the total mass of slag deposited at Consett is estimated at $8.4 \mathrm{Mt}$ to 12.6 Mt (dependent upon ratio of blast furnace to steel slag). An average $\mathrm{CaO}$ content in slag of $38-40 \%$ by weight (Euroslag 2014) was used to calculate that approximately $2.9 \mathrm{Mt}$ of calcium are stored within slag heaps at Consett ( $\mathrm{Ca}$ occurring as $\mathrm{CaO}$ ). Flux estimates of Ca were calculated for an area of the River Derwent upstream and downstream of the confluence of the Dene and Howden Burn to calculate metal loads over time. From 1991 to 2003, it was calculated that over $2400 \mathrm{t} \mathrm{Ca}$ have been introduced to the Derwent from the combined output of the Dene and Howden Burn (i.e. leached from slag heaps), a figure representing under $1 \%$ of the total $\mathrm{Ca}$ stored within the slag heaps. While it would be anticipated that a large inventory of Ca-oxides would carbonate over time in the heaps (e.g. Renforth et al. 2009), this relatively low flux of Ca over this time period, coupled with the continued signal of hydroxide 
alkalinity in both streams (i.e. $\mathrm{pH}>10.3$ ), suggests that readily weathered $\mathrm{Ca}$-oxides can remain an enduring long-term source of pollution to the aqueous environment.

\section{Management of alkaline wastes}

The hydro-geochemistry of steel slag drainage waters can pose a threat to the surface water environment through elevated $\mathrm{pH}$ (Roadcap et al. 2005), elevated metal(loid) concentrations and the smothering of benthic habitats by rapid formation of calcite precipitates (Hull et al. 2014; Koryak et al. 2002). As such, pollution management and control is of importance, especially with view of restoring the affected stream systems to their former uncontaminated state. The management of alkaline waste sites such as steel slag disposal heaps can take one of two approaches: active or passive.

Active management involves an ongoing effort to counter the effects of the pollution, which generally requires more capital input and consumes more resources. During ongoing production at Consett Iron and Steelworks, both the Howden Burn and Dene Burn were actively dosed with sulphuric acid in attempts to maintain stream $\mathrm{pH}$ at a lower level. Acid dosing is also a management technique used elsewhere to treat alkaline waste discharges, such as in the aftermath of the bauxite processing residue (red mud) spill at Ajka, Hungary in 2010, where acid dosing lowered $\mathrm{pH}$ and minimised mobility of various oxyanionic metals and metalloids (Burke et al. 2013). Given the resource requirements, alongside the health and safety issues of handling and applying concentrated chemical reagents, such interventions are unlikely to be suitable at legacy sites. Passive management generally involves less intrusive measures to remediate pollution at a much lower long-term cost (Younger 2000). The use of wetlands to treat alkaline steel slag leachate was documented by Mayes et al. (2006, 2009a) in the UK and by Banks et al. (2006) in the USA. The high $\mathrm{CO}_{2}$ content of wetland waters were reported to enhance calcite precipitation, which in turn reduced total alkalinity and $\mathrm{pH}$. Although passive management has advantages (e.g. lower operating costs), the applicability of wetlands have spatial and topographical constraints. The geography of Dene and Howden Burn, within moderately narrow and steep ravines (Fig. 1), would exclude the use of buffering wetlands as a potential option for remediation, as the flat land necessary is not available based on the rough empirical sizing guidance currently available (Mayes et al. 2006). Given these constraints, management approaches are limited in the case of Consett.

A broader issue for managing such sites centres on partitioning of environmental liability, given the company responsible for the enduring pollution issue is no longer in existence and pollution from steel represents one of a number of legacy pollution pressures that government agencies ultimately take responsibility for under over-arching environmental legislation (the EU Water Framework Directive in particular). In the UK, significant progress has been made with managing some legacy pollutant sources, notably those from coal mines (Johnston et al. 2008) and more recently metal mines (Mayes et al. 2013). However, legacy steel mill pollution has not been directly addressed, which is something of a concern given the continued retreat of the steel industry in the UK and the imminent need for developing robust post-closure plans. The model for management approaches to these problems may be seen in the USA where the very successful community-focussed watershed associations are in a position to leverage remedial funds out of state and federal departments. An example is the Nine Mile Run in Pittsburgh, Philadelphia, historically affected by highly alkaline slag leachate (Koryak et al. 2002) where major investment facilitated by the watershed association has seen the capturing and diversion of highly alkaline leachates in amongst broader watershed restoration measures (Bain et al. 2014). This has prevented the occasional very high $\mathrm{pH}$ (up to 11.3: Koryak et al. 2002) being apparent in lower reaches of the stream (Bain et al. 2014).

\section{Conclusions}

Laboratory leaching tests have been used previously to generate large datasets of aqueous and solid phases within slag leachates (e.g. De Windt et al. 2011; Fällman 2000). Less studied, however, is the long-term evolution of leachates under ambient environmental conditions at large disposal sites. The findings presented here from a unique 36year dataset, particularly the observed temporal patterns of $\mathrm{Ca}$ concentration, alkalinity and $\mathrm{pH}$, highlight the longevity of pollution generated by legacy steelworks pollution. Trends in Ca showed consistent decline in both of the streams draining slag deposits, which when coupled with 
Ca flux calculations, is consistent with the depletion of calcium oxides and silicates in slag deposits over time. Based on rates of decline in $\mathrm{Ca}$ at the affected streams, it is likely to be a timescale of decades before drainage waters no longer cause excess carbonate precipitation and high $\mathrm{pH}$ that impact on water quality. This work highlights the value of in-situ study of legacy steel slag deposits in order to gain better insight to the evolution of leachates under ambient conditions. Such data are crucial to informing site closure and post-closure environmental management programmes.

Acknowledgments This work was funded by the Natural Environment Research Council under grants NE/K015648/1 and NE/ L014211/1. The authors would like to thank the Environment Agency for provision of long-term elemental and rainfall data, as well as the Centre for Ecology and Hydrology for the issuing of gauged daily flow data. Bob Knight and Victor Uchenna Oty are thanked for laboratory analyses. We are also grateful for assistance with field sampling from Carl Thomas, Áron Anton, Katherine Abel, Alexandra Harrison, Lorna Nicholson and Thomas Shard.

\section{References}

Bain, D. J., Copeland, E. M., Divers, M. T., Hecht, M., Hopkins, K. G., Hynicka, J., Koryak, M., Kostalos, M., Brown, L., Elliott, E. M., Fedor, J., Gregorich, M., Porter, B., Smith, B., Tracey, C., \& Zak, M. (2014). Characterizing a major urban stream restoration project: Nine Mile Run (Pittsburgh, Pennsylvania, USA). Journal of the American Water Resources Association, 50(6), 1608-1621.

Ball, J.W., \& Nordstrom, D.K. (1991). User's manual for WATE Q4F, with revised thermodynamic data base and text cases for calculating speciation of major, trace, and redox elements in natural waters. USGS Open-File Report, 91-183.

Banks, M. K., Schwab, A. P., Alleman, J. E., Hunter, J. G., \& Hickey, J. C. (2006). Constructed wetlands for the remediation of blast furnace slag leachates. Indiana: Joint Transportation Research Program.

Burke, I. T., Peacock, C. L., Lockwood, C. L., Stewart, D. I., Mortimer, R. J. G., Ward, M. B., Renforth, P., Gruiz, K., \& Mayes, W. M. (2013). Behaviour of aluminum, arsenic, and vanadium during the neutralization of red mud leachate by $\mathrm{HCl}$, gypsum, or seawater. Environmental Science and Technology, 47(12), 6527-6535.

Burt, T. P., Howden, N. J. K., Worrall, F., \& McDonnell, J. J. (2011). On the value of long-term, low-frequency water quality sampling: avoiding throwing the baby out with the bathwater. Hydrological Processes, 25(5), 828-830.

Chaurand, P., Rose, J., Briois, V., Olivi, L., Hazemann, J. L., \& Proux, O. (2007). Environmental impacts of steel slag reused in road construction: a crystallographic and molecular (XANES) approach. Journal of Hazardous Materials, 139, 537-542.

Czop, M., Motyka, J., Sracek, O., \& Szuwarzyński, M. (2011). Geochemistry of the hyperalkaline Gorka Pit Lake $(\mathrm{pH}>13)$ in the Chrzanow Region, Southern Poland. Water, Air, and Soil Pollution, 214(1), 423-434.

Das, B., Prakash, S., Reddy, P. S. R., \& Misra, V. N. (2007). An overview of utilization of slag and sludge from steel industries. Resources, Conservation and Recycling, 50(1), 40-57.

De Windt, L., Chaurand, P., \& Rose, J. (2011). Kinetics of steel slag leaching: batch tests and modelling. Waste Management, 31(2), 225-235.

Euroslag. (2014). Slag: A high grade product out of a high quality controlled industry. [online] Available at: <http://www. euroslag.com/products/properties/>.

Fällman, A. M. (2000). Leaching of chromium and barium from steel slag in laboratory and field tests - a solubility controlled process? Waste Management, 20(2-3), 149-154.

Fällman, A. M., \& Hartlén, J. (1994). Leaching of slags and ashescontrolling factors in field experiments versus in laboratory tests. Studies in Environmental Science, 60, 39-54.

Ford, D. C., \& Williams, P. W. (2007). Karst geomorphology and hydrology. Chichester: Wiley.

Goetz, E. R., \& Riefler, R. G. (2014). Performance of steel slag leach beds in acid mine drainage treatment. Chemical Engineering Journal, 240, 579-588.

Hirsch, R. M., \& Slack, J. R. (1984). A nonparametric trend test for seasonal data with serial dependence. Water Resources Research, 20(6), 727-732.

Hjelmar, O. (1990). Leachate from land disposal of coal fly ash. Waste Management \& Research, 8(6), 429-449.

Howel, D., O’Brien, S., Murphy, E., Chinn, D. J., McCrone, C., French, J. M., \& Blain, P. G. (2001). Upper aerodigestive tract cancers in former employees at an iron and steel works. Occupational Medicine, 51(5), 336-342.

Hull, S. L., Oty, U. V., \& Mayes, W. M. (2014). Rapid recovery of benthic invertebrates downstream of hyperalkaline steel slag discharges. Hydrobiologia, 736(1), 83-97.

Jarvis, A. P., \& Younger, P. L. (1997). Dominating chemical factors in mine water induced impoverishment of the invertebrate fauna of two streams in the Durham Coalfield, UK. Chemistry and Ecology, 13(4), 249-270.

Jarvis, A. P., Moustafa, M., Orme, P. H. A., \& Younger, P. L. (2006). Effective remediation of grossly polluted acidic, and metal-rich, spoil heap drainage using a novel, low-cost, permeable reactive barrier in Northumberland, UK. Environmental Pollution, 143(2), 261-268.

Johnston, D., Potter, H., Jones, C., Rolley, S., Watson, I., \& Pritchard, J. (2008). Abandoned mines and the water environment. Bristol: Environment Agency.

Koryak, M., Stafford, L. J., Reilly, R. J., \& Magnuson, P. M. (2002). Impacts of steel mill slag leachate on the water quality of a small Pennsylvania stream. Journal of Freshwater Ecology, 17(3), 461-465.

Kruse, N. A., Mackey, A. L., Bowman, J. R., Brewster, K., \& Riefler, R. G. (2012). Alkalinity production as an indicator of failure in steel slag leach beds treating acid mine drainage. Environmental Earth Sciences, 67(5), 1389-1395.

Langmuir, D. (1996). Aqueous environmental geochemistry. Upper Saddle River: Prentice-Hall.

Li, Z., Zhao, S., Zhao, X., \& He, T. (2012). Leaching characteristics of steel slag components and their application in cementitious property prediction. Journal of Hazardous Materials, 199-200, 448-452. 
Libiseller, C., \& Grimvall, A. (2002). Performance of partial Mann-Kendall tests for trend detection in the presence of covariates. Environmentrics, 13(1), 71-84.

Matern, K., Rennert, T., \& Mansfeldt, T. (2013). Molybdate adsorption from steel slag eluates by subsoils. Chemosphere, 93(9), 2108-2115.

Mayes, W. M., Younger, P. L., \& Aumônier, J. (2006). Buffering of alkaline steel slag leachate across a natural wetland. Environmental Science \& Technology, 40(4), 1237-1243.

Mayes, W. M., Younger, P. L., \& Aumônier, J. (2008). Hydrogeochemistry of alkaline steel slag leachates in the UK. Water, Air, and Soil Pollution, 195(1), 35-50.

Mayes, W. M., Jarvis, A. P., \& Aumônier, J. (2009a). Preliminary evaluation of a constructed wetland for treating extremely alkaline ( $\mathrm{pH}$ 12) steel slag drainage. Water Science and Technology, 59(11), 2253-2263.

Mayes, W. M., Batty, L. C., Younger, P. L., Jarvis, A. P., Kõiv, M., Vohla, C., \& Mander, U. (2009b). Wetland treatment at extremes of pH: a review. Science of the Total Environment, 407(13), 3944-3957.

Mayes, W. M., Jarvis, A. P., Burke, I. T., Walton, M., Feigl, V., Klebercz, O., \& Gruiz, K. (2011). Dispersal and attenuation of trace contaminants downstream of the Ajka bauxite residue (red mud) depository failure, Hungary. Environmental Science \& Technology, 45(12), 5147-5155.

Mayes, W. M., Potter, H. A. B., \& Jarvis, A. P. (2013). Riverine flux of metals from historically mined orefields in England and Wales. Water, Air, and Soil Pollution, 224(2), 1-14.

Miliša, M., Kepčija, R. M., Radanović, I., Ostojić, A., \& Habdija, I. (2006). The impact of aquatic macrophyte (Salix sp. and Cladium mariscus (L.) Pohl.) removal on habitat conditions and macroinvertebrates of tufa barriers (Plitvice Lakes, Croatia). Hydrobiologia, 573(1), 183197.

Motz, H., \& Geiseler, J. (2001). Products of steel slags: an opportunity to save natural resources. Waste Management, 21(3), 285-293.

Nabizadeh, R., Mahvi, A., Mardani, G., \& Yunesian, M. (2005). Study of heavy metals in urban runoff. International Journal of Environmental Science and Technology, 1(4), 325-333.

Navarro, C., Díaz, M., \& Villa-García, M. A. (2010). Physicochemical characterization of steel slag. Study of its behavior under simulated environmental conditions. Environmental Science \& Technology, 44, 5383-5388.

NVN. (1994). Pre-standard 7347, Determination of the maximum leachable quantity and the emission of inorganic contaminants from granular construction materials and waste materials-the compacted granular leach test. Draft revised November 1996. Delft.

Parkhurst, D.L., \& Apello, C.A.J. (1999). User's guide to PHRE EQC - a computer program for speciation, batch-reaction, one-dimensional transport, and inverse geochemical calculations. U.S. Geological survey Water-Resources Investigations Report, 99-4259.

Paulauskis, J. D., \& Winner, R. W. (1988). Effects of water hardness and humic acid on zinc toxicity to Daphnia magna Straus. Aquatic Toxicology, 12(3), 273-290.

Plummer, L. N., \& Busenberg, E. (1982). The solubilities of calcite, aragonite and vaterite on $\mathrm{CO}_{2}-\mathrm{H}_{2} \mathrm{O}$ solutions between
0 and $90^{\circ} \mathrm{C}$, and an evaluation of the aqueous model for the system $\mathrm{CaCO}_{3}-\mathrm{CO}_{2}-\mathrm{H}_{2} \mathrm{O}$. Geochemica et Cosmochimica Acta, 46(6), 1011-1040.

Poultney, E. (2013). Development of a quality protocol for the use of steel slag (pp. 9-11). IJmuiden: 7th European Slag Conference.

Proctor, D. M., Fehling, K. A., Shay, E. C., Wittenborn, J. L., Green, J. J., Avent, C., Bigham, R. D., Connolly, M., Lee, B., Shepker, T. O., \& Zak, M. A. (2000). Physical and chemical characteristics of blast furnace, basic oxygen furnace, and electric arc furnace steel industry slags. Environmental Science and Technology, 34(8), 1576-1582.

R Development Core Team. (2012). R: A Language and Environment for Statistical Computing, 3-900051-07-0R. Foundation for Statistical Computing: Vienna, Austria. [online] Available at: <http://www.R-project.org/>.

Rattner, B. A., McKernan, M. A., Eisenreich, K. M., Link, W. A., Olsen, G. H., Hoffman, D. J., Knowles, K. A., \& McGowan, P. C. (2006). Toxicity and hazard of vanadium to mallard ducks (Anas platyrhynchos) and Canada geese (Branta Canadensis). Journal of Toxicology and Environmental Health, 69(3-4), 331-351.

Renforth, P., Manning, D. A. C., \& Lopez-Capel, E. (2009). Carbonate precipitation in artificial soils as a sink for atmospheric carbon dioxide. Applied Geochemistry, 24(9), 17571764.

Roadcap, G. S., Kelly, W. R., \& Bethke, C. M. (2005). Geochemistry of extremely alkaline $(\mathrm{pH}>12)$ ground water in slag-fill aquifer. Ground Water, 43, 806-816.

Roadcap, G. S., Sanford, R. A., Jin, Q., Pardinas, J. R., \& Bethke, C. M. (2006). Extremely alkaline $(\mathrm{pH}>12)$ ground water hosts diverse microbial community. Ground Water, 44(4), 511-517.

Schwab, A. P., Hickey, J., Hunter, J., \& Banks, M. K. (2006). Characteristics of blast furnace slag leachate produced under reduced and oxidised conditions. Journal of Environmental Science and Health, Part A, 41(3), 381-395.

Shen, H., \& Forssberg, E. (2003). An overview of recovery of metals from slags. Waste Management, 23(10), 933-949.

Shi, C. (2004). Steel slag - its production, processing, characteristics, and cementitious properties. Journal of Materials in Civil Engineering, 16(3), 230-236.

Smirnov, L. A., Grabeklis, A. A., \& Demin, B. L. (2009). Processing slag from ferroalloy production. Steel in Translation, 39(1), 93-96.

Tossavainen, M., \& Lind, L. (2008). Leaching results of reactive materials. Construction and Building Materials, 22(4), 566572.

Tromp, K., Lima, A. T., Barendregt, A., \& Verhoeven, J. T. A. (2012). Retention of heavy metals and poly-aromatic hydrocarbons from road water in a constructed wetland and the effect of de-icing. Journal of Hazardous Materials, 203-204, 290-298.

Younger, P. L. (1997). The longevity of minewater pollution: a basis for decision-making. Science of the Total Environment, 194-195, 457-466.

Younger, P. L. (2000). Holistic remedial strategies for short- and long-term water pollution from abandoned mines. Mining Technology, 109(3), 210-218. 
Younger, P. L., \& Banwart, S. A. (2002). Time-scale issues in the remediation of pervasively-contaminated groundwaters at abandoned mine sites. IAHS-AISH Publication, 275, 585-592.

Younger, P. L., Coulton, R. H., \& Froggatt, E. C. (2005). The contribution of science to risk-based decision-making: lessons from the development of full-scale treatment measures for acidic mine waters at Wheal Jane, UK. Science of the Total Environment, 338(1-2), 137154.
Zaihua, L., Svensson, U., Dreybrodt, W., Daoxian, Y., \& Buhmann, D. (1995). Hydrodynamic control of inorganic calcite precipitation in Huanglong Ravine, China: field measurements and theoretical prediction of deposition rates. Geochemica et Cosmochimica Acta, 59, 3087-3097.

Zhuo, L., Li, H., Cheng, F., Shi, Y., Zhang, Q., \& Shi, W. (2012). Co-remediation of cadmium-polluted soil using stainless steel and ammonium humate. Environmental Science and Pollution Research, 19(7), 2842-2848. 